\title{
PENGARUH KUALITAS PELAYANAN TERHADAP KEPUASAN PELANGGAN JASA PENERBANGAN BATIK AIR PADA PT. LION GROUP DI BANDARA SULTAN SYARIF KHASIM II PEKANBARU
}

\author{
Jeli Nata Liyas \\ Jurusan Manajemen Fakultas Ekonomi STIE RIAU \\ jaznatan@yahoo.co.id
}

\begin{abstract}
This study aims to determine the effect of service quality on customer satisfaction at Sultan Syarif Khasim II Airport Pekanbaru. Using a sample of 100 people. In this study the authors use descriptive and quantitative research methods using SPSS method.From the result of research, the value of titung variable of service quality is 20,764 and table value is 1,660 , so $t_{\text {count }}>t_{\text {table }}(20,764>1,660)$ and significant value 0,000 $<0,05$, so it can be concluded that service quality variable positively and significant customer satisfaction. The value of $R$ square $=0,815$ means $81,5 \%$ influence of independent variable (Service Quality) to dependent variable (Customer Satisfaction) equal to $81,5 \%$ and while remaining 18,5\% influenced by other variable not examined. Finally from this study can be concluded that customer satisfaction has a positive and significant impact on customer satisfaction, so it is advisable to Air Batik airline to be able to maintain and continue to improve the quality of service.
\end{abstract}

Keywords: Service Quality, and Customer Satisfaction

Penelitian ini bertujuan untuk mengetahui pengaruh kualitas layanan terhadap kepuasan pelanggan di Bandara Sultan Syarif Khasim II Pekanbaru. Menggunakan sampel sebanyak 100 orang. Dalam penelitian ini penulis menggunakan metode penelitian deskriptif dan kuantitatif menggunakan metode SPSS. Dari hasil penelitian, nilai $\mathrm{t}_{\text {hitung }}$ variabel kualitas pelayanan adalah 20,764 dan nilai $t_{\text {tabel }}$ adalah 1,660, sehingga $t_{\text {hitung }}>t_{\text {tabel }}$ $(20,764>1,660)$ dan nilai signifikan $0,000<0,05$, sehingga dapat disimpulkan bahwa variabel kualitas layanan berpengaruh positif dan signifikan terhadap kepuasan pelanggan. Nilai $\mathrm{R}$ square $=0,815$ berarti $81,5 \%$ pengaruh variabel independen (Kualitas Layanan) terhadap variabel dependen (Kepuasan Pelanggan) sebesar 81,5\% dan sementara sisanya $18,5 \%$ dipengaruhi oleh variabel lain yang tidak diteliti. Akhirnya dari ini Penelitian dapat disimpulkan bahwa kepuasan pelanggan memiliki dampak positif dan signifikan terhadap kepuasan pelanggan, sehingga disarankan kepada maskapai Air Batik untuk dapat mempertahankan dan terus meningkatkan kualitas layanan.

Kata kunci: Kualitas Layanan, dan Kepuasan Pelanggan 


\section{PENDAHULUAN}

Efek multiplier yang ditimbulkan bisnis penerbangan akhir-akhir ini cukup tinggi karena merangsang tumbuhnya industri jasa seperti hotel, catering dan lain-lain. Sehingga tenaga kerja yang di butuhkan akan semakin bertambah dengan tumbuhnya perusahaan penunjang, sehingga perputaran roda ekonomi semakin cepat. Batik Air adalah perusahaan jasa penerbangan yang masih belia (baru) di sini Batik Air konsentari dengan target penumpang kalangan menengah ke atas. Dimana terdapat 2 kelas pada setiap penerbangan, yaitu kelas Bisnis dan ekonomi.

Dalam hal ini Batik Air menggunakan 2 tipe pesawat yaitu pesawat bertipe Airbus 320 dengan jumlah penumpang 12 bisnis dan 148 ekonomi dan Boeing 737-800 dengan jumlah penumpang 12 bisnis dan 160 ekonomi, keadaan di dalam pesawat sama, hanya bedanya ukuran pesawat saja. Di sini batik air memberikan pelayanan yang sangat maksimal dari awal checkin sampai duduk di pesawat. Pada awal checkin penumpang sudah disuguhkan dengan keramah tamahan dan petugas checkin dan disambut oleh ambassador batik yang tidak kalah cantik dan gantengnya dengan pramugari dan pramugara, di dalam pesawat kita juga disuguhkan dengan keramahtamahan pramugari dan pramugara. Batik air juga memberikan fasilitas menonton di dalam pesawat yang di setiap kursi disediakan LED untuk menonton, penumpangnya jangan pernah kuatir kelaparan ketika di pesawat karena Batik Air memberikan layanan makanan di atas pesawat.

Awal pertama batik air terbang membuka promo upgrade dari ekonomi ke bisnis hanya tambah 300.000 ribu. Dan fasilitas launge untuk penumpang yang menggunakan kelas bisnis dari sini terbukti bahwa Batik Air sedang memperkenalkan bahwa Batik Air, pesawat yang bernaungan di bawah perusahaan Lion Group ini membuka penerbangan untuk Bisnis class.

Dan tidak itu saja, tahun pertama Batik Air masuk kedunia perbangan on time performance mencapai $88,59 \%$ dimana Batik Air menjelaskan bahwa pesawatnya layak di mata masyarakat, dan menunjukkan bahwa pelayanan dan kepuasan pelanggan di utamakan. Karena dalam sebuah penerbangan ketepatan waktu sangat dibutuhkan untuk dapat membuat pelanggan puas.

Untuk lebih jelasnya berikut ini akan disajikan data jumlah on time performance batik selama 3 tahun. Terhitung 2013 s/d tahun 2015 yang dapat dilihat melalui tabel berikut ini :

Tabel 1. Tabel Data On Time Performance Maskapai Yang Memiliki Persentase Tertinggi Tahun 2013-2016

\begin{tabular}{|c|c|c|c|c|c|c|c|}
\hline \multirow[b]{2}{*}{ NO } & \multirow[b]{2}{*}{ TAHUN } & \multicolumn{3}{|c|}{ MASKAPAI } & \multicolumn{3}{|c|}{ JUMLAH PENERBANGAN } \\
\hline & & $\begin{array}{l}\text { BATIK } \\
\text { AIR }\end{array}$ & $\begin{array}{l}\text { NAM } \\
\text { AIR }\end{array}$ & $\begin{array}{l}\text { GARUDA } \\
\text { INDONESIA }\end{array}$ & $\begin{array}{l}\text { BATIK } \\
\text { AIR }\end{array}$ & $\begin{array}{c}\text { NAM } \\
\text { AIR }\end{array}$ & $\begin{array}{l}\text { GARUDA } \\
\text { INDONESIA }\end{array}$ \\
\hline 1 & 2013 & $88,59 \%$ & - & $84,05 \%$ & 5.344 & - & 168.374 \\
\hline 2 & 2014 & $90,78 \%$ & $92,92 \%$ & $88,52 \%$ & 13.535 & 3.477 & 164.623 \\
\hline 3 & 2015 & $91,21 \%$ & $90,61 \%$ & $85,82 \%$ & 25.617 & 8.248 & 77.955 \\
\hline 4 & 2016 & $94,81 \%$ & $91,13 \%$ & $89,91 \%$ & 25.617 & 8.248 & 77.955 \\
\hline
\end{tabular}

Sumber : Dekrorat Jendral Penerbangan Udara 2016 
Dari data di atas dapat disimpulkan bahwa on time performance Batik Air berada pada tingkatan pertama di mana dari tahun 2013-2015 Batik Air menduduki peringkat pertama di on time performance, pada tahun 2013 Batik Air mendapat persentasi 88,59\% dari jumlah penerbangan 5.344, Garuda Indonesia menduduki peringkat kedua dengan persentasi on time performance $84,05 \%$ dengan jumlah penerbangan 168.374, pada tahun 2014 Batik Air masih bertahan dengan posisinya dengan nilai persentasi on time performance $90,78 \%$, kali ini di peringkat kedua diduduki Nam Air anak usaha dari Sriwijaya Air dengan jumlah persentasi $90,61 \%$ dengan jumlah penumpang 3.477, dan peringkat ketiga ada Garuda Indonesia dengan persentasi $85,82 \%$ dengan jumlah penerbangan 164.623. Pada tahun 2015 posisi pertama masih diduduki oleh maskapai anak usaha dari Lion Group dengan jumlah persentasi on time performance 91,21\% dengan jumlah penerbangan 25.617, sedangkan posisi kedua masih diduduki oleh Nam Air dengan persentasi 90,61\% dengan jumlah penerbangan 8.248 , sedangkan untuk garuda jumlah persetasi $85,82 \%$ dengan jumlah penerbangan 77.955. Pada tahun 2016 jumlah persentasi dari semua maskapai mencapai 99,13\% peringkat pertama masih diduduki oleh Lion Group yaitu maskapai Batik Air dengan jumlah persentasi 94,81\% dengan jumlah penerbangan 25.617, no urut kedua diduduki oleh maskapai Nam Air dengan jumlah persentasi $91,13 \%$ dengan jumlah penerbangan 8.248 , dan no urut ketiga diduduki oleh Garuda Indonesia dengan jumlah persentasi $89,91 \%$ dengan jumlah penerbangan 77.955 .

Tabel 2. Layanan Kepuasan Pelanggan Yang Diberikan Batik Air

\begin{tabular}{lcc}
\hline \multicolumn{1}{c}{ FASILITAS } & BISNIS & EKONOMI \\
\hline Free Lounge & YA & TIDAK \\
Free bagasi & $30 \mathrm{Kg}$ & $20 \mathrm{Kg}$ \\
Bagasi Keluar Pertama & YA & TIDAK \\
Luas kursi 45" pitch & YA & TIDAK \\
Makanan di atas pesawat & YA & YA \\
Film yang disediakan di atas pesawat & YA & YA \\
\hline
\end{tabular}

Sumber PT. Lion Group 2013

Dari data di atas dapat disimpulkan bahwa ada perbedaan antara pelayanan penumpang bisnis class dan ekonomi, untuk penumpang yang membeli tiket bisnis class mendapat free lounge sedangkan ekonomi tidak, untuk class bisnis mendapat free bagasi $30 \mathrm{~kg}$ sedangkan ekonomi mendapat free bagasi $20 \mathrm{~kg}$, bagasi penumpang bisnis keluar pertama sehingga tidak perlu menunggu sedangkan penumpang ekonomi harus menunggu bagasi di tempat pengambilan bagasi, jarak antara kursi satu dengan yang lainnya lebih luas class bisnis dibanding dengan class ekonomi, untuk kelas bisnis dan ekonomi semuanya mendapatkan makanan di atas pesawat, dan di setiap kursi bisnis maupun ekonomi terdapat film yang dapat diputar di saat pesawat mengudara. 
Tabel 3. Jumlah Penumpang Maskapai Batik Air Di Bandara SSK 2 Pekanbaru Tahun 2013 S/D 2016

\begin{tabular}{ccccc}
\hline TAHUN & BISNIS & EKONOMI & TOTAL & PERSENTASE \\
\hline 2013 & 3180 & 59370 & 90450 & - \\
2014 & 6480 & 121200 & 127680 & $37,2 \%$ \\
2015 & 10560 & 143120 & 153680 & $26,0 \%$ \\
2016 & 14400 & 205200 & 219600 & $65,9 \%$ \\
\hline
\end{tabular}

Sumber : PT. Lion Group Pekanbaru 2017

Berdasarkan data di atas jumlah penumpang bisnis tahun 2013 sebanyak 3180 dan ekonomi sebanyak 59370 dengan total 90450 jumlah persentasenya belum ada karena ini menjadi awal tahun berdirinya Batik Air di Pekanbaru, tahun 2014 penumpang bisnis 6480, ekonomi 121200 dengan total 127680 dan persentasenya adalah 37,2\%, tahun 2015 penumpang bisnis 10560 ekonomi 143120 dengan total 153680 dan jumlah persentasenya adalah 26,0\%, tahun 2016 penumpang ekonomi sebanyak 14400 penumpang ekonomi sebanyak 205200 dengan total 219600 dan jumlah persentasenya adalah $65,9 \%$.

Tabel 4. Jumlah Keluhan Pelanggan Penumpang Batik Air Di Sultan Syarif Khasim II Pekanbaru

\begin{tabular}{|c|c|c|c|}
\hline $\mathrm{NO}$ & TAHUN & $\begin{array}{c}\text { JUMLAH } \\
\text { KELUHAN }\end{array}$ & JENIS KELUHAN \\
\hline 1. & 2013 & 0 & TIDAK ADA \\
\hline 2. & 2014 & 3 & $\begin{array}{l}\text { - Terlalu cepat boarding, terkadang } \\
\text { tidak sesuai dengan scedjul yang } \\
\text { tertera pada boarding pass, sehingga } \\
\text { membuat penumpang terburu-buru. } \\
\text { - Petugas kurang ramah. } \\
\text { - Pintu gate yang tidak menentu }\end{array}$ \\
\hline 3. & 2015 & 4 & $\begin{array}{l}\text { - Kekurangan meal. } \\
\text { - Tidak memakai garbarata, atau } \\
\text { tangga manual. } \\
\text { - Penumpang bisnis tidak didampingi } \\
\text { ambassador. } \\
\text { - Tidak ada prioritas untuk penum- } \\
\text { pang yang menggunakan member } \\
\text { Batik Air. }\end{array}$ \\
\hline 4. & 2016 & 5 & $\begin{array}{l}\text { - Pelanggan bisnis tidak dapat meng- } \\
\text { gunakan lounge, Batik Air tidak ada } \\
\text { kerjasama dengan lounge Bandara } \\
\text { Pekanbaru } \\
\text { - Mobil bisnis tidak wangi. } \\
\text { - Karpet mobil bisnis tidak bersih. } \\
\text { - Tidak adanya countre checkin } \\
\text { - khusus untuk penumpang bisnis. } \\
\text { - Pintu gate tidak menentu. }\end{array}$ \\
\hline
\end{tabular}


Dari data di atas dapat disimpulkan bahwa pada tahun 2013 Batik Air tidak memiliki keluhan, pada tahun 2014 jumlah pelanggan yang mengeluh ada 3 orang, ada 2 jenis keluhannya yaitu boarding terlalu cepat tidak sesuai dengan scedjul yang tertera pada boarding pass sehingga membuat penumpang terburu-buru. Keluhan dan petugas yang kurang ramah. Pada tahun 2015 jumlah pelanggan yang mengeluh ada 5 orang, ada 3 jenis keluhan yaitu kekurangan meal, tidak memakai garbarata, atau tangga manual dan penumpang bisnis tidak didampingi Ambasador. Pada tahun 2016 terdapat 4 pelanggan, ada 3 jenis keluhan yaitu pelanggan bisnis tidak dapat menggunakan lounge, Batik Air tidak ada kerjasam dengan lounge Bandara Pekanbaru, Mobil bisnis tidak wangi, karpet mobil bisnis tidak wangi dan tidak adanya countre checkin khusus untuk penumpang bisnis.

Tabel 5. Target Penjualan Yang Harus Dicapai Oleh PT. Batik Air Di Bandar Udara SSK di Pekanbaru Tahun 2013 S/D 2016

\begin{tabular}{cccc}
\hline Tahun & Target Penjualan & Realisasi & Persentasi \\
\hline 2013 & 55000 & 90450 & $1,644 \%$ \\
2014 & 100.000 & 127680 & $1,276 \%$ \\
2015 & 140.000 & 153680 & $1,097 \%$ \\
2016 & 180.000 & 219600 & $1,22 \%$ \\
\hline
\end{tabular}

Sumber : PT. Lion Group Pekanbaru 2017

Dari data di atas dapat disimpulkan bahwa pada tahun 2013 target penjualan sebesar 55.000 terealisasi 90450 dengan persentasi $1,644 \%$, pada tahun 2014 target penjualan 100.000 terealisasi 127680 dengan persentasi $1,276 \%$, tahun 2015 target penjualan 140.000 terealisasi 153680 dengan persentasi $1,097 \%$, pada tahun 2016 target penjualan 180.000 terealisasi 219600 dengan persentasi $1,22 \%$.

Dari uraian di atas, penulis ingin membahas lebih jauh tentang kualitas pelayanan dengan memilih judul: "Pengaruh Kualitas Pelayanan Terhadap Kepuasan Pelanggan Jasa Penerbangan Batik Air pada PT. Lion Group di Bandara Sultan Syarif Khasim II Pekanbaru".

\section{METODE PENELITIAN}

Populasi dalam penelitian ini adalah seluruh penumpang Batik Air tahun 2016 dengan jumlah 219600. Beberapa rumus untuk menentukan jumlah sampel antara lain:
Rumus Slovin (dalam Riduwan, 2005:65)

$\mathrm{n}=\mathrm{N} / \mathrm{N}(\mathrm{d})^{2}+1$

$\mathrm{n}=$ sampel; $\mathrm{N}=$ populasi $\mathrm{d}=$ nilai presisi $90 \%$ atau sig. $=0,1$.

Jumlah populasi adalah 219600, dan tingkat kesalahan yang dikehendaki adalah 10\%, maka jumlah sampel yang digunakan adalah: $\mathrm{N}=219600 / 219600(0,1)^{2}+1=100$ orang (dibulatkan).

Dalam penulisan ini, metode pengumpulan data yang penulis tempuh adalah kuesioner dan wawancara. Metode Analisis Data dengan Model persamaan Regresi Linier Sederhana adalah seperti berikut ini :

$\mathrm{Y}=\mathrm{a}+\mathrm{bX}$

Dimana: Y: Variabel Response atau Variabel Akibat (Dependent)

X: Variabel Predictor atau Variabel

Faktor Penyebab (Independent)

a: Konstanta

b: Koefisien regresi (kemiringan), besaran Response yang ditimbulkan oleh prediktor. 
HASIL DAN PEMBAHASAN Analisis Regresi Linear Sederhana

Analisis regresi linier sederhana adalah hubungan secara linier antara satu variabel independent $(\mathrm{x})$ dengan variabel dependent (y)

Tabel 6. Hasil Analisis Regresi Linier Sederhana

\section{Coefficients ${ }^{\mathrm{a}}$}

\begin{tabular}{|c|c|c|c|c|c|c|}
\hline & & \multicolumn{2}{|c|}{$\begin{array}{c}\text { Unstandardized } \\
\text { Coefficients }\end{array}$} & \multirow{2}{*}{$\begin{array}{c}\text { Standardized } \\
\text { Coefficients } \\
\text { Beta }\end{array}$} & \multirow[b]{2}{*}{$\mathrm{t}$} & \multirow[b]{2}{*}{ Sig. } \\
\hline \multicolumn{2}{|c|}{ Model } & B & Std. Error & & & \\
\hline 1 & (Constant) & 3.656 & 1.499 & & 2.439 & .017 \\
\hline & $\begin{array}{l}\text { Kualitas } \\
\text { pelayanan }\end{array}$ & .534 & .026 & .903 & 20.764 & .000 \\
\hline
\end{tabular}

a. Dependent Variable: kepuasan pelanggan

Sumber : Data olahan Tahun 2017

Berdasarkan pengolahan data pada tabel di atas dapat dirumuskan model persamaan regresi linier sederhana sebagai berikut :

$\mathrm{Y}=3.656+0,534$

Analisisnya :

1. Nilai konstanta $(\alpha)$ bernilai 3.656 artinya jika variabel kualitas pelayanan $=0$, maka kepuasan pelanggan (y) sebesar 3.656

2. Nilai koefisien regresi (b) dari variabel kualitas pelayanan sebesar $(0,534)$, artinya setiap peningkatan kualitas pelayanan sebanyak $1 \%$, maka kepuasan pelanggan akan meningkat 0,534

\section{Uji Hipotesis}

a. Koefisien determinasi $\left(\mathrm{R}^{2}\right)$

Koefisien determinasi $\left(\mathrm{r}^{2}\right)$ digunakan untuk mengukur seberapa jauh kemampuan model dalam menerangkan variasi dependen. Nilai koefisien determinasi adalah antara 0 dan 1 . Nilai $\left(\mathrm{r}^{2}\right)$ yang kecil berarti kemampuan variabel-variabel independen dalam menjelaskan variasivariasi dependen amat terbatas.

Tabel 7. Hasil Uji $\mathrm{R}^{2}$

\begin{tabular}{lrrrr} 
Model & R & R Square & Adjusted R Square & \multicolumn{2}{c}{$\begin{array}{c}\text { Std. Estror of the } \\
\text { Estimate }\end{array}$} \\
\hline 1 & $.903^{\mathrm{a}}$ & .815 & .813 & 2.96298 \\
\hline
\end{tabular}

Sumber : Data Olahan Tahun 2017

Dari tabel di atas menunjukkan bahwa : nilai $\mathrm{R}=0,903$ berarti hubungan antara variabel bebas (kualitas pelayanan) terhadap variabel terikat (kepuasan pelanggan) sebesar $90,3 \%$ artinya hubungannya sangat erat. Nilai R square = 0,815 berarti $81,5 \%$. Pengaruh variabel bebas (Kualitas Pelayanan) terhadap variabel terikat (Kepuasan Pelanggan) sebesar $81,5 \%$ dan sedangkan sisanya 
sebesar $18,5 \%$ dipengaruhi variabel lain yang tidak diteliti.

b. Ujit

Uji t digunakan untuk mengetahui ada tidaknya hubungan atau pengaruh yang berarti (signifikan) antara variabel independen (kualitas pelayanan) secara persial terhadap variabel dependen (kepuasan pelanggan). Cara menggunakan tabel statistik pada signifikan 0,05 dengan derajat kebebasan $(\mathrm{df})=\mathrm{n}-2$. Dengan $\mathrm{n}$ adalah jumlah sampel yang digunakan 98. Dan $\mathrm{df}=98$. Sehingga hasil yang diperoleh untuk t tabel sebesar : 1,660 (tabel statistics).

Tabel 8. Hasil Uji Signifikan Parsial (Uji T)

\begin{tabular}{|c|c|c|c|c|c|c|}
\hline & & \multicolumn{2}{|c|}{$\begin{array}{c}\text { Unstandardized } \\
\text { Coefficients }\end{array}$} & \multirow{2}{*}{$\begin{array}{c}\text { Standardized } \\
\text { Coefficients } \\
\text { Beta }\end{array}$} & \multirow[b]{2}{*}{$\mathrm{T}$} & \multirow[b]{2}{*}{ Sig. } \\
\hline \multicolumn{2}{|c|}{ Model } & B & Std. Error & & & \\
\hline 1 & (Constant) & 3.656 & 1.499 & & 2.439 & .017 \\
\hline & $\begin{array}{l}\text { Kualitas } \\
\text { pelayanan }\end{array}$ & .534 & .026 & .903 & 20.764 & .000 \\
\hline
\end{tabular}

Sumber : Sumber Data Tahun 2017

Nilai $t_{\text {hitung }}$ variabel kualitas pelayanan adalah 20,764 dan nilai $t_{\text {tabel }}$ adalah 1,660 sehingga $t_{\text {hitung }}>t_{\text {tabel }}(20.764>1,660)$ dan nilai signifikan $0,000<0,05$, sehingga dapat disimpulkan bahwa variabel kualitas pelayanan berpengaruh secara positif dan signifikan terhadap kepuasan pelanggan.

\section{PENUTUP}

\section{Simpulan}

Berdasarkan hasil penelitian yang telah dilakukan oleh penulis pada uraian bab-bab sebelumnya, mengenai pengaruh Kualitas Pelayanan terhadap Kepuasan Pelanggan di Bandar Udara Sultan Syarif Khasim II Pekanbaru, maka berikut ini penulis dapat mengambil simpulan:

a. Kualitas Pelayanan pada maskapai Batik Air termasuk dalam kategori "Setuju". Sesuai dengan tabel 5.23, dengan jumlah frekuensi jawaban 1500 dan rata-rata skor $3,80 \%$ yang merujuk ke skala likert masuk ke dalam kategori setuju. Hal ini menunjukkan bahwa responden / penumpang maskapai Batik Air setuju akan pernyataan-pernyataan yang terdapat di dalam kuisioner variabel kualitas pelayanan $(\mathrm{X})$.

b. Kepuasan pelanggan pada maskapai Batik Air termasuk dalam kategori "Setuju". Sesuai dengan tabel 5.33, dengan jumlah frekuensi jawaban 900 dan rata-rata skor $3,41 \%$ yang merujuk ke skala likert masuk kedalam kategori setuju. Hal ini menunjukkan bahwa responden / penumpang maskapai Batik Air setuju akan pernyataan-pernyataan yang terdapat di dalam kuisioner variabel Kepuasan pelanggan (Y).

c. Pada pengujian koefisien determinasi $\left(\mathrm{R}^{2}\right)$ didapat nilai $\mathrm{R}=0,903$ berarti hubungan antara variabel kualitas pelayanan terhadap kepuasan pelanggan sebesar 90,3\% artinya hubungannya sangat erat. Nilai $\mathrm{R}$ 
square $=0,815$ yang berarti pengaruh variabel kualitas pelayanan terhadap kepuasan pelanggan pada maskapai Batik Air sebesar $81,5 \%$. Dan sisanya sebanyak $18,5 \%$ dipengaruhi oleh variabel lain yang tidak diteliti.

d. Nilai $t_{\text {hitung }}$ variabel kualitas pelayanan adalah 20,764 dan nilai $t_{\text {tabel }}$ adalah 1,660 sehingga $\mathrm{t}_{\text {hitung }}>\mathrm{t}_{\text {tabel }}(20.764>1,660)$ dan nilai signifikan $0,000<0,05$, sehingga dapat disimpulkan bahwa variabel kualitas pelayanan berpengaruh secara positif dan signifikan terhadap kepuasan pelanggan pada maskapai Batik Air.

\section{Saran}

Berdasarkan simpulan penelitian, maka penulis merekomendasikan saran-saran sebagai berikut:

a. Maskapai Batik Air disarankan untuk terus menjaga kualitas pelayanan jasa pada Maskapai Batik Air dalam rangka mempertahankan eksistensi di industri penerbangan di mata para pelanggannya, karena pada dasarnya apabila elemen program kepuasan pelanggan dilakukan dengan baik maka pelanggan akan menuju kepada pembelian ulang.

b. Maskapai Batik Air harus terus mengontrol variabel efeksi positif, efeksi negatif kualitas dan diskonfirmasi. Pada pemikiran negatif aspek yang perlu diperhatikan yaitu masih cenderungnya pelanggan merasa khawatir dan takut mengalami hal-hal buruk selama penerbangan harus segera dihilangkan oleh pihak Batik Air dengan cara mengedepankan segi safety yang tinggi bertaraf internasional sehingga pada akhirnya pelanggan merasa yakin terhadap keselamatan penerbangan sehingga dapat meredam pemikiran negative dari diri pelanggan.

c. Pada aspek kualitas pelayanan maskapai
Batik Air dapat memaksimalkannya yaitu dengan segi hiburan dan makanan yang disajikan selama penerbangan. Jika ini dapat dilakukan oleh maskapai Batik Air maka akan meningkatkan kepuasan pelanggan.

d. Diharapkan pula kepada maskapai Batik Air agar selalu melakukan inovasi baru dan senantiasa mengevaluasi programprogram layanan untuk meningkatkan nilai kepuasan pelanggan agar apa yang di terima dan dirasakan pelanggan jauh di atas pengharapan atau ekspetasi pelanggan.

\section{DAFTAR PUSTAKA}

Buyung (2013). Analisis Kualitas Pelayanan Kepada Kepuasan Konsumen Pada Minimarket Alfamart Makassar, Universitas Hasanudin.

Djafar, Friet F. (2013). Analisis Pengaruh Kepuasan Pelayanan Terhadap Kepuasan Pelanggan di Grand City Hotel Gorontalo Universitas Negri Gorontalo.

Kolter, dkk, 2007. Management Pemasaran Edisi Kedua Belas. Indeks : Jakarta.

Lovelosk, Christoper H. dan Wright, Lauren K. 2005. Manajemen Pemasaran Jasa. Indeks Hal. 102.

Manullang Ida (2008). Analisis Kepuasan Pelanggan PT Garuda Indonesia di Bandara Polonia Medan, Universitas Sumatra Utara.

Sugiyono, (2009). Metode Penelitian Bisnis (Pendekatan Kuantitatif, Kualitatif, dan $R \& D)$ Bandung : Alfabeth.

Tjiptono, Fandy dan Gregorius Chandra, 2012 , Pemasaran Strategik. Yogyakarta, ANDI. 
Umar, Husein (2011). Metode Penelitian Untuk Skripsi dan Tesis Bisnis. Edisi 11. Jakarta: PT. Raja Grafindo Persada.

Yazid, 2008. Pemasaran Jasa Edisi Kedua. Yogyakarta : Ekonosia Kamus Fakultas VII.

Zeithaml, Valarie A. and Britner, Mary Jo. Service Marketing McGraw Hill Inc, Int'l Edition, New York, 2003 